University of Nebraska - Lincoln

DigitalCommons@University of Nebraska - Lincoln

USDA Wildlife Services - Staff Publications

U.S. Department of Agriculture: Animal and

Plant Health Inspection Service

August 2006

\title{
A Simulation Model for Determining Cost-Effectiveness of Fences for Reducing Deer Damage
}

\author{
Kurt C. VerCauteren \\ USDA-APHIS-Wildlife Services, kurt.c.vercauteren@usda.gov \\ Michael J. Lavelle \\ USDA/APHIS/WS National Wildlife Research Center, michael.j.lavelle@aphis.usda.gov \\ Scott E. Hygnstrom \\ University of Nebraska-Lincoln, shygnstrom1@unl.edu
}

Follow this and additional works at: https://digitalcommons.unl.edu/icwdm_usdanwrc

Part of the Environmental Sciences Commons

\begin{abstract}
VerCauteren, Kurt C.; Lavelle, Michael J.; and Hygnstrom, Scott E., "A Simulation Model for Determining Cost-Effectiveness of Fences for Reducing Deer Damage" (2006). USDA Wildlife Services - Staff Publications. 106.

https://digitalcommons.unl.edu/icwdm_usdanwrc/106
\end{abstract}

This Article is brought to you for free and open access by the U.S. Department of Agriculture: Animal and Plant Health Inspection Service at DigitalCommons@University of Nebraska - Lincoln. It has been accepted for inclusion in USDA Wildlife Services - Staff Publications by an authorized administrator of DigitalCommons@University of Nebraska - Lincoln. 


\title{
A Simulation Model for Determining Cost-Effectiveness of Fences for Reducing Deer Damage
}

\author{
KURT C. VerCAUTEREN, ${ }^{\mathbf{1}}$ United States Department of Agriculture/Animal and Plant Health Inspection Service/Wildlife Services/National Wildlife \\ Research Center, Fort Collins, CO 80521-2154, USA \\ MICHAEL J. LAVELLE, United States Department of Agriculture/Animal and Plant Health Inspection Service/Wildlife Services/National Wildlife Research \\ Center, Fort Collins, CO 80521-2154, USA \\ SCOTT E. HYGNSTROM, School of Natural Resources, University of Nebraska, Lincoln, NE 68583-0819, USA
}

\begin{abstract}
The installation of fences to protect agricultural products, natural resources, or other areas from deer (Odocoileus spp.) can be expensive and potential benefits of fencing are difficult to quantify. A rational method is needed to help evaluate whether fencing can be cost-effective and which fence designs will be optimal for particular applications. We describe an interactive, dynamic simulation model that conducts economic analyses and predicts economic benefit associated with fences for crops relative to area and perimeter of protected plot, value of crop, percentage of crop damaged by deer annually prior to fencing, efficacy of fence, and costs of fence materials and labor. Users of the model can easily adjust these variables to fit their individual situations and needs. By running a series of simulations, model users can answer questions related directly to fence efficacy and cost-effectiveness. (WILDLIFE SOCIETY BULLETIN 34(1):16-22; 2006)
\end{abstract}

\section{Key words}

cost, damage, deer, exclusion, fence, model, Odocoileus spp., wildlife damage management.

Historically, efforts to manage wildlife damage seldom have been evaluated economically (Dyer and Ward 1977, Caslick and Decker 1979, Caughley 1980, Dolbeer 1988). Researchers have placed more emphasis on determining statistical significance of experiments than on evaluating economic significance (Dillon 1977). Efforts to exclude deer (Odocoileus spp.) usually are expensive. Those who choose not to erect a fence often assume the benefits of fencing would not exceed the costs. Conversely, those who choose to construct a fence assume the benefits of fencing will exceed the costs. An economic evaluation of damage caused by deer and costs required to control that damage through fencing is necessary to determine if fencing is cost-effective.

Agricultural producers generally tolerate crop loss approaching $10 \%$ due to wildlife damage (Craven et al. 1992, Craven and Hygnstrom 1994). Conover (1998) reported that $80 \%$ of producers experienced wildlife damage and that the amount of damage exceeded the tolerance of $53 \%$ of them. Agricultural damage is most often caused by deer and each year deer cause $\$ 100$ million (U.S.) damage to crop production and $\$ 750$ million to the timber industry (Conover 2002). Wywialowski (1996) reported that among the top 10 corn-producing states, damage caused by deer exceeded $\$ 30$ million in 1993. In New York an average annual loss of $\$ 15,000 /$ grower in apple production was reported (Purdy et al. 1987). Other deer damage of major economic importance includes collisions with automobiles and aircraft and transmission of diseases to livestock and humans.

Effective control of deer damage requires integrated management involving lethal and nonlethal strategies (DeNicola et al. 2000). The primary means of deer population management is through hunting, though hunting is not safe, effective, or acceptable in all situations. A good fence can be a long-term, year-round solution to deer damage. For situations when damage occurs within a shorter time frame, seasonal fences can be an effective option.

\section{${ }^{1}$ E-mail: kurt.c.vercauteren@aphis.usda.gov}

Little is known about overall cost-effectiveness of specific methods to control damage by deer. Benefit-cost analysis is a generic term that encompasses a broad range of evaluation procedures for estimating monetary gains and losses associated with a particular level of activity (Sassone and Schaffer 1978). Costs refer to increases in something undesirable (i.e., damage) or lost opportunities to benefit (McAllister 1980). Benefits refer to a gain in something desirable (i.e., income) or reduction of something undesirable (Hone 1994). When benefits exceed costs, the activity will be economically profitable. The net present value (NPV) is the benefit-cost analysis term that is most telling for situations regarding the discounting of benefits and costs into the future to decide among alternative options (Ruth and Hannon 1997). The NPV compares the value of a dollar today to its value in the future, or in this case, over the life of a particular fence design. The NPV is an important consideration when deciding to fence or not to fence, and if to fence then which design would maximize income. Though economic analyses are good criteria for making decisions, they are difficult to conduct (Cherrett et al. 1971). Determining inputs required to obtain accurate NPVs is challenging in dynamic settings like agricultural and forest ecosystems. See Shwiff (2004) for more information on economic analyses applied in wildlife damage management scenarios, including deer fencing.

Though complex, economic modeling of systems is worthwhile (VerCauteren et al. 2002). The modeling of system dynamics improves comprehension and conceptualization of the varying and interacting components that function within a system (Richmond 1993, Forrester 1994). System-dynamics models are interactive and allow users to provide their own inputs and learn through simulation. Simulations (running the model several times with different input values) allow for efficient generation and testing of hypotheses and scenarios (Risenhoover et al. 1997). A model on fence selection related to deer damage will help users make 
informed decisions regarding the fencing options they are considering.

Our overall goal was to develop a parsimonious model that would 1) identify the variables and interactions that influence fence selection, and 2) identify which fence designs will perform best given specific input parameters, minimizing fence-related expenditures while maximizing damage reduction. Our Best Fence Selection Model (BFSM) ultimately will elucidate NPV trends associated with variables pertaining to deer damage and fencing options.

\section{Model Development}

The BFSM is the product of an exhaustive search of the scientific literature (i.e., Agricola, Agris, Biological \& Agricultural Index, Biosis, Dissertation Abstracts, Elsevier Biobase, Enviroline, General Sci, Life Science Collection, Mantis, SciSearch) on the topic of deer fencing; key words included damage, deer, exclusion, fence, cost, model, and wildlife damage management. We also collected product literature from several fencing manufacturers and other nonscientific sources. We organized and synthesized the literature into a comprehensive review paper on deer fencing (VerCauteren et al. 2006). The BFSM incorporates what was learned through the review and puts it into a usable format that is of value to wildlife managers, farmers, suburban residents, highway departments, airport authorities, and others who may consider fencing as an option to reduce damage inflicted by deer. There are several fence designs that are used commonly and they all have different characteristics (Table 1).

We determined material costs by contacting 40 fence suppliers and contractors across the United States through their websites and by telephone conversations. We based labor costs on an industry estimate of $50 \%$ of material costs for fences that are easy to erect (e.g., baited electric) to $90 \%$ for permanent and more difficult to erect fences. Material and labor costs vary among suppliers and contractors and increase with additional corners, ends, gates, and installation on rough terrain. Model users can adjust installation costs associated with their unique situation and incorporate them into the model. Maintenance costs also are dependent on several factors including terrain, durability of fence, weather, habitat, and animal activity. For example, an electric fence installed in an area with high rainfall and lush vegetation will require more effort in vegetation suppression to eliminate grounding than it would in an arid environment. Regardless of fence cost, some maintenance will be necessary. Some maintenance costs will be expected (e.g., vegetation suppression, inspections) while others will be unexpected (e.g., trees falling on fence, failure of electric fence charger). As maintenance costs vary among situations and occur over the life of the fence, they are not incorporated into the model. Users, therefore, should take into consideration what their annual maintenance costs may be.

We constructed the BFSM with STELLA 8 simulation software (High Performance Systems, Hanover, New Hampshire). Minimum system requirements to run the model include Windows 3.1, a 486 processor, $8 \mathrm{MB}$ Ram, and $16 \mathrm{MB}$ of hard disk space. Besides STELLA modeling software, QuikTime ${ }^{\mathrm{rt}}$ software also is required. Though the model was created on an IBM-based personal computer, it can be executed on a Macintosh system (see the STELLA FAQ for instructions on exporting the model to a Macintosh system).

The model consists of 3 layers: an interactive controls layer, a model diagram layer, and an equations layer. The purpose of the layering is to manage complexity, for both producers and consumers of the model (STELLA Technical Documentation 1997). In the controls layer, users can run simulations under varying values for inputs associated with the area and resources to be protected, as well as for parameters associated with the selected fence (Fig. 1). Default values in the model pertain to a square, 8.1ha (20-acre) field of carrots that was experiencing $20 \%$ damage by deer annually prior to fencing. The default fence is a $2.4 \mathrm{~m}-(8$ foot) tall woven-wire fence that cost $\$ 6 / \mathrm{m}$ for materials and $\$ 5 / \mathrm{m}$ for labor to install. The fence is $99 \%$ effective in excluding deer and will last for 35 years. Users of the model can modify values that pertain to their fencing situation (general ranges of parameters are given in Table 1). The model calculates NPVs for each simulation. Simulations are displayed in a table on the controls layer and the NPV for each year over the life of the fence is reported. These NPVs can be compared among simulations and

Table 1. Comparison of a variety of fences for managing damage caused by deer and their characteristics including: cost (materials + labor), efficacy, longevity, and maintenance.

\begin{tabular}{|c|c|c|c|c|c|}
\hline Fence type & Cost/m (\$) & Height (m) & Efficacy (\%) & Longevity (yrs) & Maintenance \\
\hline Woven wire & $10.00-5.00$ & 2.40 & $90-99$ & $30-40$ & Low \\
\hline Welded wire & $10.00-15.00$ & 2.40 & 90-99 & $20-30$ & Low \\
\hline Chain link & $>20.00$ & 2.40 & $90-99$ & $30-40$ & Low \\
\hline Poly. mesh & $15.00-20.00$ & 2.40 & 90-99 & $10-20$ & Medium \\
\hline Poly. rope 9 & $5.00-10.00$ & 1.82 & $70-80$ & $15-25$ & High \\
\hline Mod. WW $3 \mathrm{HT}^{\mathrm{a}}$ & $5.00-10.00$ & 2.40 & $80-90$ & $20-30$ & Medium \\
\hline Poly. snow ${ }^{b}$ & $5.00-10.00$ & 2.12 & $80-90$ & $15-25$ & Medium \\
\hline Offset HT & $2.00-5.00$ & 1.05 & $60-70$ & $20-30$ & High \\
\hline Slanted $7 \mathrm{HT}^{\mathrm{C}}$ & $2.00-5.00$ & 1.50 & $70-80$ & $20-30$ & High \\
\hline Penn St. $5 \mathrm{HT}$ & $2.00-5.00$ & 1.12 & $70-80$ & $20-30$ & High \\
\hline Poly. tape $2^{d}$ & $<2.00$ & 0.90 & $60-70$ & $5-15$ & High \\
\hline Baited electric & $<2.00$ & 1.12 & $80-90$ & 10-20 & High \\
\hline
\end{tabular}




\section{"Best Fence" Selection Model}

\section{Field and Crop Parameters}

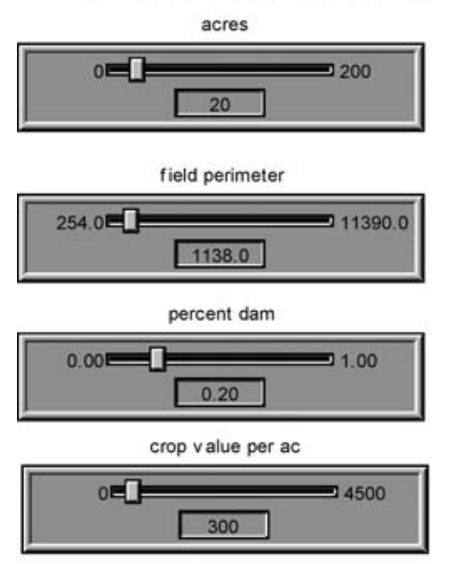

\section{Fence Parameters}

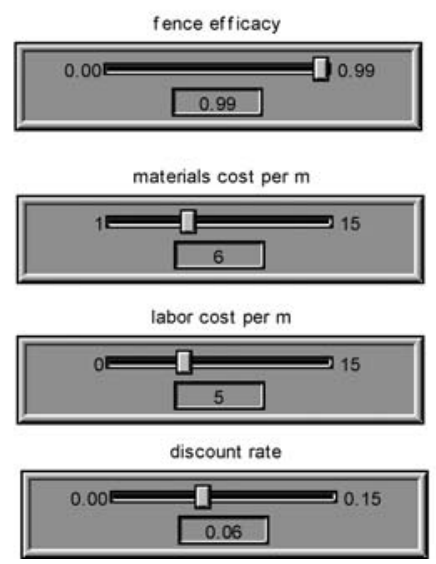

Figure 1. The STELLA controls layer of the Best Fence Selection Model.

reveal after how many years the upfront cost of the fence was recovered in reduced damages.

The second layer of the model is called the diagram layer. It shows the layout of the model variables and their relationships with each other (Fig. 2). The diagram layer gives the user a detailed representation of these relationships. The third layer lists equations depicted in the second layer, allowing the interested user to more completely understand the functioning of the model and the system. If desired, the advanced user could modify aspects of the model in the second or third layer.

The model allows the user to input situation-specific values for size of the area to be protected (ha), level of damage caused by deer in previous years $(\%)$, value of the crop/ha, material and labor cost of a given fence design $/ \mathrm{m}$, perimeter of the area to be protected $(\mathrm{m})$, expected efficacy of the fence design as related to the situation $(\%)$, life expectancy of the fence, and current

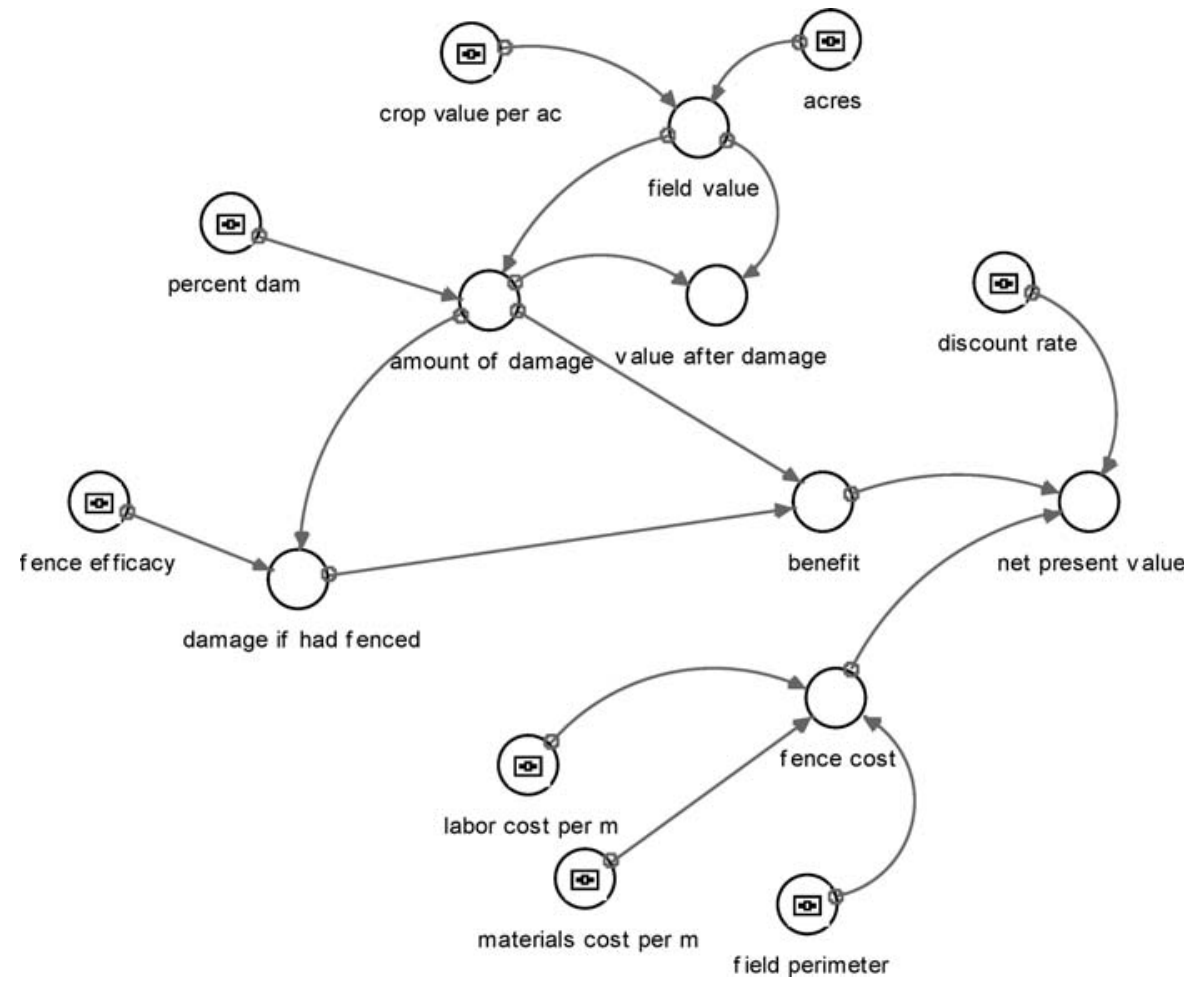

Figure 2. The STELLA diagram layer of the Best Fence Selection Model. 
Table 2. Yield and value of 5 crops commonly damaged by deer. Values taken from United States Department of Agriculture/National Agricultural Statistics Service website: http://www.usda.gov/nass/ for year 2002.

\begin{tabular}{|c|c|c|c|c|c|}
\hline \multirow[b]{2}{*}{ Crop } & \multicolumn{2}{|c|}{ Yield } & \multicolumn{3}{|c|}{ Value } \\
\hline & Per ha & Per ac & Market & \$/ha & $\$ / a c$ \\
\hline Soybeans & $3,292.00 \mathrm{~L}$ & $37.80 \mathrm{Bu}$ & $\$ 5.48 / \mathrm{Bu}$ & 512 & 207 \\
\hline Alfalfa & 7.15 tonnes & 3.19 tons & $\$ 100.00 /$ ton & 788 & 319 \\
\hline Carrots (processing quality) & 57.59 tonnes & 25.69 tons & $\$ 70.00 /$ ton & 4,444 & 1,798 \\
\hline Cranberries & 16.90 tonnes & 7.54 tons & $\$ 652.00 /$ ton & 12,148 & 4,916 \\
\hline Apples (fresh) & 23.76 tonnes & 10.60 tons & $\$ 526.00 /$ ton & 13,777 & 5,576 \\
\hline
\end{tabular}

discount rate. Life expectancy of the fence is modified by clicking on Run Specs and changing the length of simulation (the value in the "To" box). Values for all other variables are modified by simply adjusting the sliders on the variable's control (Fig. 1). The more accurate the values provided by the user, the greater the confidence in model output. By varying inputs for parameters that may be "educated guesses," (i.e., annual percent of damage, crop value, fence efficacy) the user can run simulations for best- and worst-case scenarios to get a complete understanding of how a given fence can be expected to perform.

\section{Model Simulation}

To gain an understanding of how varying input values impact the economics of fencing, and to demonstrate the model, we ran simulations for each type of fence listed in Table 1 and varied the input values for crop value, field size, and amount of damage. We set values for the other variables to the defaults listed above. We began by varying crop value to reflect the income per hectare that would be expected from 5 crops of differing values (listed from lowest to highest value): soybeans, alfalfa, carrots, cranberries, and apples (Table 2). The NPVs for each of the 12 fence designs protecting 5 crop types varied considerably (Fig. 3 ). For the least valuable crops (soybeans and alfalfa), several of the most effective fences had negative NPVs, because these fences were also the most expensive. For the other crops, fencing always led to positive NPVs and the more valuable the crop the higher the NPV. The NPVs for some of the polypropylene fences were low relative to other fence types because of their shorter lifespans. The NPV for 2 -strand polypropylene tape was the lowest because besides a comparatively short lifespan, the fence is less effective. The NPVs associated with some lower-cost fences of moderate-to-low efficacy (on the right of Fig. 3) was highest for crops of lower value. For low-value crops such as soybeans, not fencing may be the most practical option given the low NPV for even the best fence alternatives (simple electric fence designs).

To elucidate how the size of the area to be protected impacted the NPVs, we examined square soybean fields and apple orchards of 0.4 ha, 8.1 ha, and 81 ha (Fig. 4). As the field size increases across fence types, so does the NPV, resulting in a greater incentive to fence. For soybeans, fencing fields of 81 ha yielded positive NPVs, but for fields 0.4 ha in size, the investment in fencing was not recovered in saved yield. For high-value crops like apples, fencing any size field with all but the expensive or shortlived designs proved profitable. Only the electric fence designs (excluding 2-strand polypropylene tape) on an 8.1 ha field yielded positive NPVs for soybeans. Especially on larger fields, fencing is a

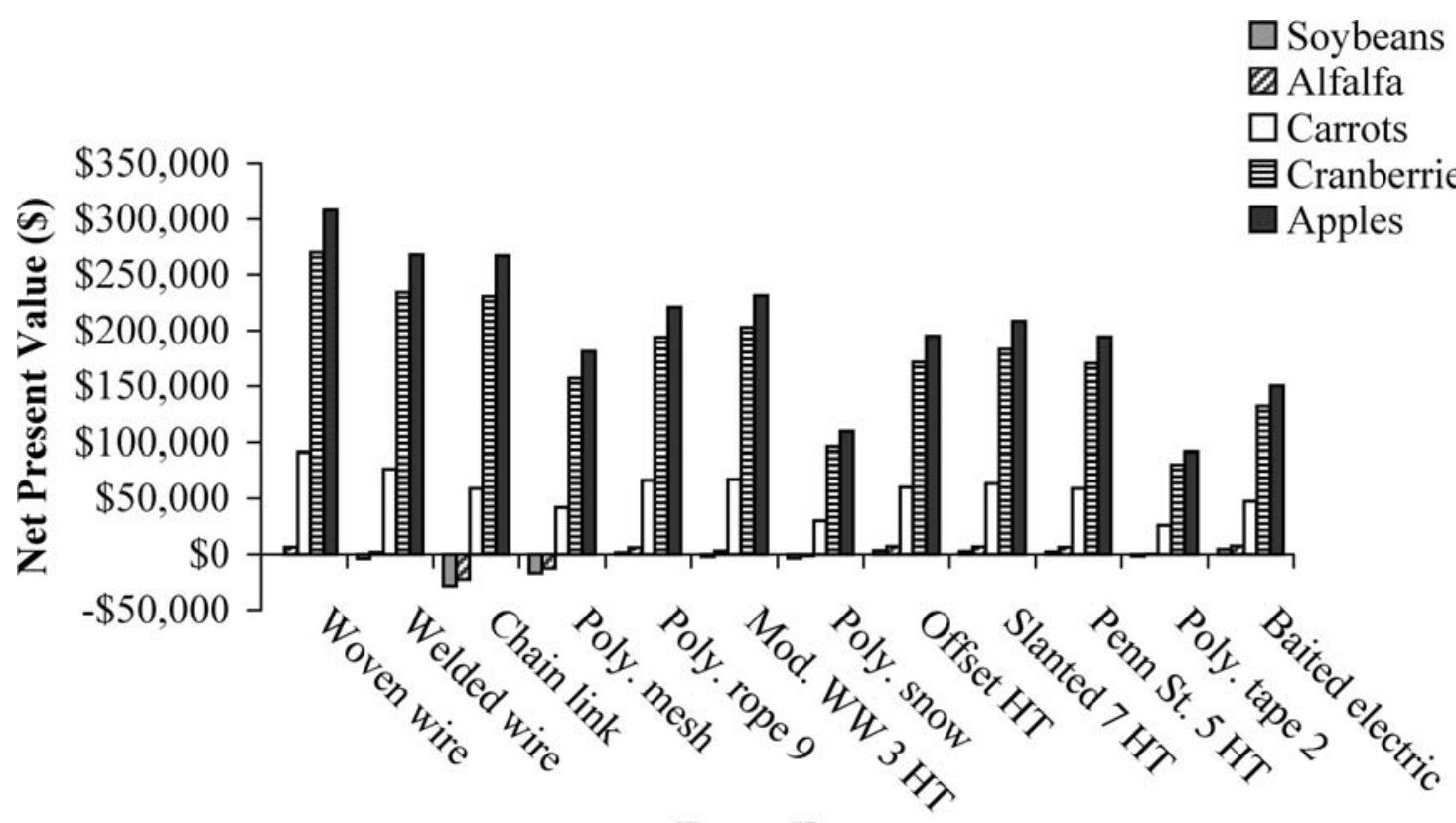

Fence Type

Figure 3. The net present values for 5 crop types when protected by 12 types of fence. 
A) Apple Orchard

$\square 0.4$ ha

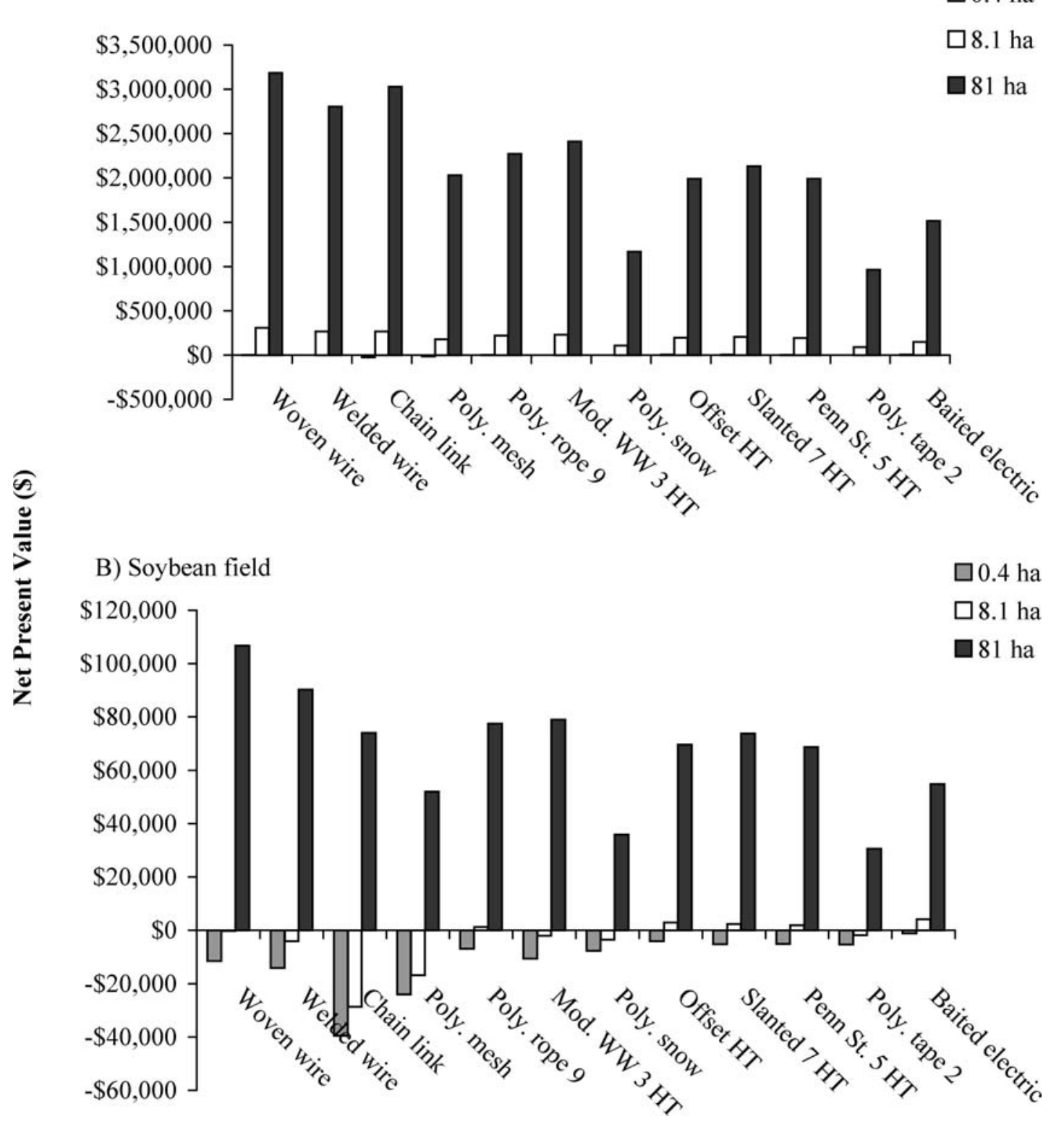

Figure 4. Net present values associated with 12 types of fence protecting 3 sizes of fields $(0.4,8.1$, and 81 ha) of (A) apples and (B) soybeans.

sound decision to maximize income because, as field size increases, field perimeter increases at a decreasing rate (VerCauteren et al. 2006). Rectangular areas are more cost effective (lower cost/unit area) to fence because the majority of cost of most fences is in the corner and end systems. Therefore, an effort should be made to minimize the number of gates and corners.

Next, we examined how annual damage rates prior to fencing impacted NPVs associated with the 12 types of fence. With the defaults (therefore representing a square, 8.1 ha field of carrots) and the damage rate set at $5 \%, 20 \%$, and $40 \%$ we noted trends similar to when field size was varied. Net present values were highest when the amount of prior damage was highest. When damage to soybeans was low before fencing, more expensive fences, though more effective, were not as sound an economic decision. When the crop being protected was more valuable, like apples, all types of fence yielded a positive NPV (Fig. 5). With a less valuable crop like soybeans, primarily inexpensive, longlasting fences resulted in positive NPVs and only when damage was high. Net present values increased proportionally with increased damage rates.

\section{Summary and Management Implications}

A tool has long been needed by wildlife managers and agricultural producers to aid in determining if fencing is an economically sound means of reducing damage to crops by deer. Our BFSM provides NPV analyses and predicts the economic outcomes associated with fencing relative to the area and perimeter of the protected plot, value of the crop, percentage of the crop damaged annually prior to fencing, cost of the fence, and efficacy of the fence. Users of the model can easily determine NPVs associated with fencing alternatives by adjusting these variables to fit their individual situations and interests. By running simulations they 
A) Apple orchard

$5 \%$ Damage

$\square 20 \%$ Damage

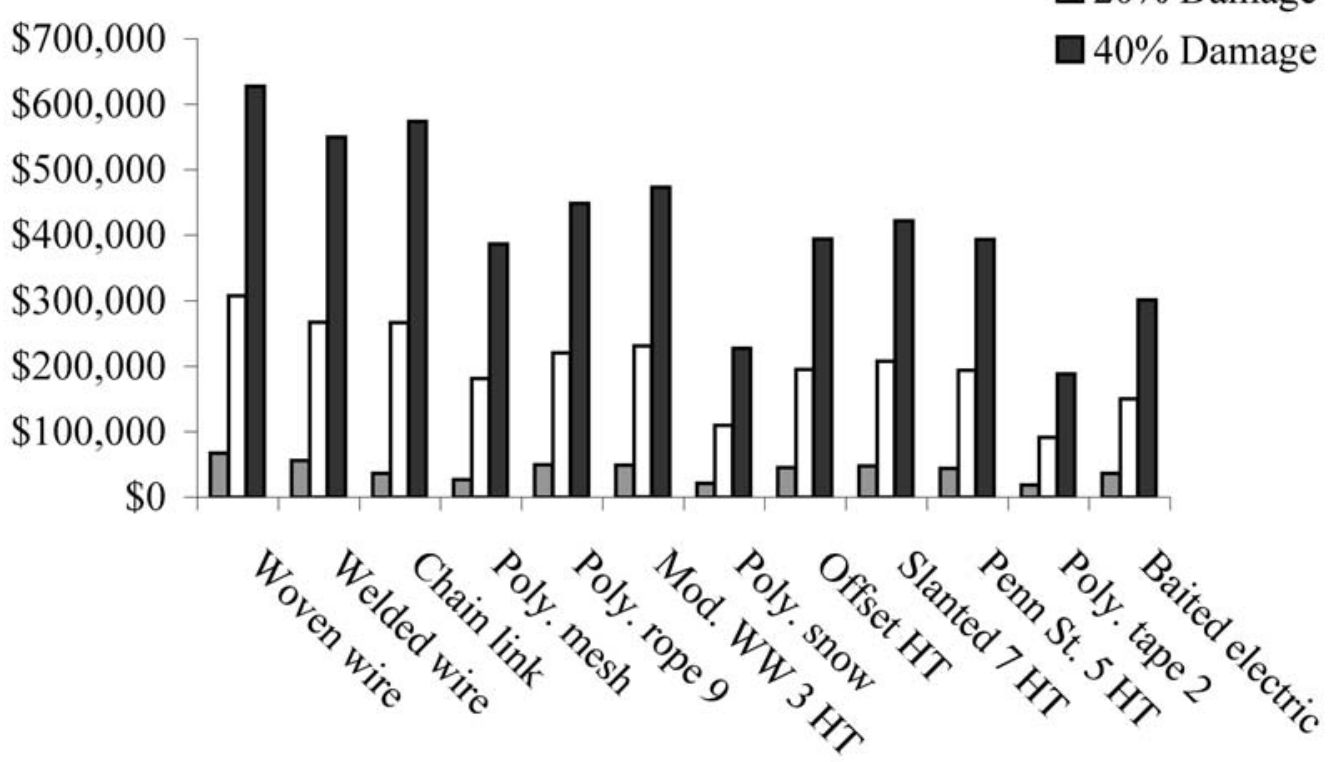

()

B) Soybean field

$\square 5 \%$ Damage

$\square 20 \%$ Damage

$\$ 20,000 \div \square 40 \%$ Damage

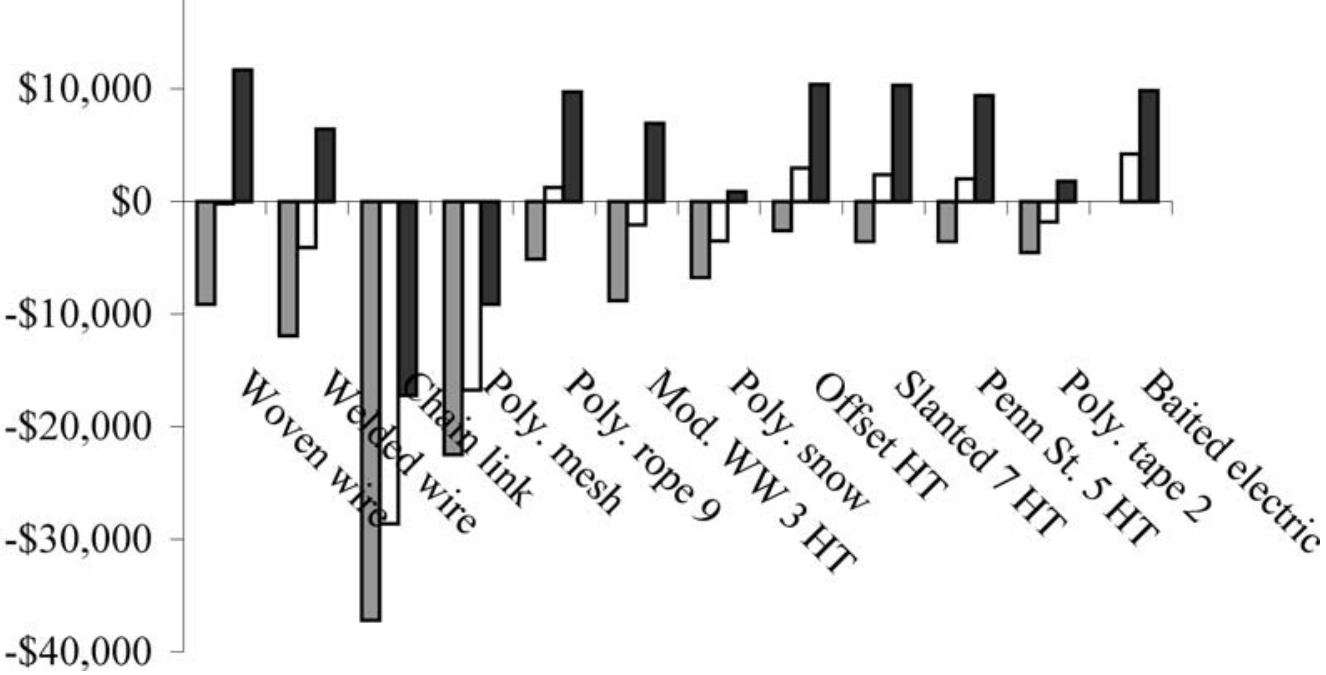

Figure 5. Net present values associated with 12 types of fence for 3 levels of damage (5\%, 20\%, and 40\%) by deer for square 8.1 ha fields of: (A) apples and (B) soybeans.

can answer questions associated with fencing options that will aid in making economically prudent decisions. Model output includes NPVs for each year of a fence's life, so users can easily compare the values of different fences over time. Individuals interested in acquiring the BFSM model may contact the authors. We also will continue to promote the BFSM through United States Department of Agriculture, Animal and Plant Health Inspection Service, Wildlife Services personnel.

The model can increase the awareness of users regarding the income that can be realized through fencing and it can aid in selecting the best fence for the situation. Further, it may help a producer determine the best crop for a situation. Damage to annual crops affect only that year's growth and yield, whereas damage to perennial crops, like apples, affect not only that year's growth and yield but also impacts productivity for years into the future. As fencing involves a considerable investment of capital, many producers have not seriously considered fencing as a viable option. The BFSM will allow producers to more easily understand if their income could be increased over the long term if they were to invest in a fence. Some caution must be exercised when using economic models because inaccuracies in parameter values, multiplicative error, and violated assumptions can lead to spurious 
results (Maynard-Smith 1974). It is important that input values be as accurate as possible. Users should simulate best- and worse-case scenarios that could reflect changes in parameter values (especially resource values) in the future. Users can even vary the discount rate to compare fencing to alternative uses of their funds. For extremely valuable resources and those in which a value can not be easily assigned (like human lives, which could be saved by fencing roadways to prevent deer-vehicle collisions) the most effective fences (e.g., >10-m-tall woven wire) are warranted. Robert Frost

\section{Literature Cited}

Caslick, J. W., and D. J. Decker. 1979. Economic feasibility of a deer-proof fence for apple orchards. Wildlife Society Bulletin 7:173-175.

Caughley, G. 1980. Analysis of vertebrate populations. John Wiley and Sons, London, England.

Cherrett, J. M., J. B. Ford, I. V. Herbert, and A. J. Probert. 1971. The control of injurious animals. English Universities, London, England.

Conover, M. R. 1998. Perceptions of American agricultural producers about wildlife on their farms and ranches. Wildlife Society Bulletin 26:597-604.

Conover, M. R. 2002. Resolving human-wildlife conflicts: the science of wildlife damage management. CRC Press LLC, Boca Raton, Florida, USA.

Craven, S. R., D. J. Decker, S. E. Hygnstrom, and W. F. Siemer. 1992. Survey use and landowner tolerance in wildlife damage management. North American Wildlife and Natural Resource Conference 57:75-88.

Craven, S. R., and S. E. Hygnstrom. 1994. Deer. Pages D25-40 in S. E. Hygnstrom, R. M. Timm, and G. E. Larson, editors. Prevention and control of wildlife damage. University of Nebraska Cooperative Extension, Lincoln, Nebraska, USA.

DeNicola, A. J., K. C. VerCauteren, P. D. Curtis, and S. E. Hygnstrom. 2000. Managing white-tailed deer in suburban environments. Cornell University Cooperative Extension, Ithaca, New York, USA.

Dillon, J. L. 1977. The analysis of response in crop and livestock production. Second edition. Permagon, Oxford, England.

Dolbeer, R. A. 1988. Current status and potential of lethal means of reducing bird damage in agriculture. Pages 474-483 in H. Ouellet, editor. Acta XIX Congressus Internationalis Ornithologici. University of Ottawa, Ottawa, Ontario, Canada.

Dyer, M. I., and P. Ward. 1977. Management of pest situations. Pages 267300 in J. Pinowski, and S. C. Kendeigh, editors. Granivorous birds in ecosystems. Cambridge University, New York, New York, USA.

Forrester, J. W. 1994. Learning through system dynamics as preparation for the $21^{\text {st }}$ century. Systems thinking and modeling conference. 27-29 June 1994, Concord Academy, Concord, Massachusetts, USA.

Hone, J. 1994. Analysis of vertebrate pest control. Cambridge University, Cambridge, England.

Maynard-Smith, J. 1974. Models in ecology. Cambridge University, New York, New York, USA.

McAllister, D. M. 1980. Evaluation in environmental planning. Massachusetts Institute of Technology, Cambridge, Massachusetts, USA.

Purdy, K. G., W. F. Siemer, G. A. Pomerantz, and T. L. Brown. 1987. Deer damage control preferences and use decisions of New York orchardists. Proceedings of the Eastern Wildlife Damage Control Conference 3:118-127.

Richmond, B. 1993. Systems thinking: critical thinking skills for the 1990s and beyond. System Dynamics Review 9:113-133.

Risenhoover, K. L., H. B. Underwood, W. Yan, and J. L. Cooke. 1997. A spatially explicit modeling environment for evaluating deer management strategies. Pages 366-379 in W. J. McShea, H. B. Underwood, and J. H. Rappole, editors. The science of overabundance: deer ecology and population management. Smithsonian Institute, Washington, D.C., USA.

Ruth, M., and B. Hannon. 1997. Modeling dynamic economic systems. Springer-Verlag, New York, New York, USA.

Sassone, P. G., and W. A. Schaffer. 1978. Cost-benefit analysis: a handbook. Academic, New York, New York, USA.

Shwiff, S. A. 2004. Economics in wildlife damage management studies: common problems and some solutions. Proceedings of the Vertebrate Pest Conference 21:346-349.

STELLA Technical Documentation. 1997. High performance systems. Hanover, New Hampshire, USA.

VerCauteren, K. C., S. E. Hygnstrom, R. M. Timm, R. M. Corrigan, J. G. Beller, stated that "Good fences make good neighbors." It is unlikely he intended this statement to apply to deer, but it does and our model will help in the selection of "good fences."

\section{Acknowledgments}

We thank S. Shwiff, her expertise and advice in economic analyses was invaluable. The reviews of J. Fischer, G. Phillips, and 2 anonymous referees have made this a better manuscript.

L. L. Bitney, M. C. Brumm, D. Meyer, D. R. Virchow, and R. W. Wills. 2002. Development of a model to assess rodent control in swine facilities. Page 59-64 in L. Clark, J. Hone, J. Shivik, R. Watkins, K. VerCauteren, and J. Yoder, editors. Human conflicts with wildlife: economic considerations. United States Department of Agriculture/Wildlife Services/National Wildlife Research Center, Fort Collins, Colorado, USA.

VerCauteren, K. C., M. J. Lavelle, and S. E. Hygnstrom. 2006. Fences and deer-damage management: a review of designs and efficacy. Wildlife Society Bulletin 34:191-200.

Wywialowski, A. P. 1996. Wildlife damage to field corn in 1993. Wildlife Society Bulletin 24:264-271.

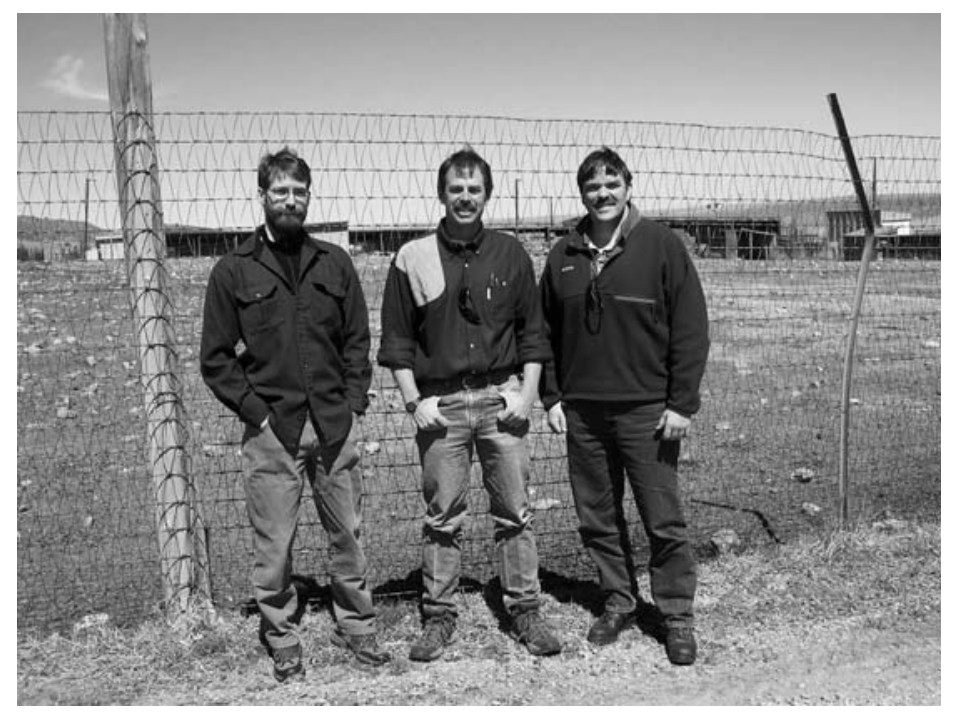

Kurt C. VerCauteren (center) is the Chronic Wasting Disease Project Leader for the Wildlife Disease Research Program of the National Wildlife Research Center. He received his B.S. from the University of WisconsinStevens Point, and M.S. and Ph.D. from the University of Nebraska-Lincoln. Kurt is a Certified Wildlife Biologist and has been on the board of the Wildlife Damage Management Working Group, served as Secretary of the Colorado Chapter of the Wildlife Society, and as President and Secretary of the Nebraska Chapter. His current research involves devising means to reduce transmission and to manage Chronic Wasting Disease and Bovine Tuberculosis in wild and captive cervids. Michael $\boldsymbol{J}$. Lavelle (left) is a Biological Technician for the Wildlife Disease Research Program of the National Wildlife Research Center. He received his B.S. from the University of Nebraska-Lincoln and is working toward his M.S. from Colorado State University. His research focuses on interactions of cervids and associated risk of disease transmission. Scott E. Hygnstrom (right) is a professor in the School of Natural Resources at the University of Nebraska-Lincoln specializing in wildlife damage management. He received his B.S. from the University of Wisconsin-River Falls, M.S. from the University of WisconsinStevens Point, and Ph.D. from the University of Wisconsin-Madison. Scott is a Certified Wildlife Biologist and is a past-chair of the Wildlife Damage Management Working Group.

Associate editor: Grado. 